\title{
Analysis of Factors Affecting Muslim Traders (Case Study of Palakka Market Fruit Traders Bone District)
}

\author{
Agus Salim Harrang ${ }^{1)}$, Asriati ${ }^{2}$, Andi Rustam ${ }^{3}$, Samsul Rizal ${ }^{4}$ \\ ${ }^{1,2,3,4}$ Faculty of Economics and Business, University of Muhammadiyah Makassar \\ *E-mail Korespondensi: agussalim.hr@unismuh.ac.id
}

\begin{abstract}
This study aims to determine the factors that affect the income of fruit traders in Palakka Market, Bone Regency. The population in this study was fruit traders in Palakka Market, Bone Regency, the number of samples in this study was 97 respondents. Sampling is used by using a system random sampling, the technique is a sampling technique where all individuals in the population. The results of data analysis research that is known states that trading capital, trading hours, and trading experience each have a significant effect on the income of traders. $R$ Square value of 0.503 means that $50.3 \%$ of the factors affecting fruit traders' income can be explained by trading capital, trading hours and trading experience, while $49.7 \%$ is explained in other factors not examined in this study. The study is useful for fruits trader in increasing their income.
\end{abstract}

Keywords: Trading capital, trading hours, trading experience, fruit traders

Citation suggestions: Harrang, A. S., Asriati., Rustam, Andi., \& Rizal, S. (2020). Analysis of Factors Affecting Muslim Traders (Case Study of Palakka Market Fruit Traders Bone District). Jurnal Ilmiah Ekonomi Islam, 6(02), 304-314. doi: http://dx.doi.org/10.29040/jiei.v6i2.1013

DOI: $\underline{\text { http://dx.doi.org/10.29040/jiei.v6i2.1013 }}$

\section{INTRODUCTION}

Development countries, including Indonesia, certainly carry out development efforts. The development was carried out in various sectors including the economic sector, the political sector, the socio-cultural sector and others. The development effort was carried out to develop the economy in Indonesia in order to improve the standard of living of the people and bring Indonesia into the era of modernization.

One of the developments currently being carried out by the government is through economic development. Economic development leads to policies taken by the government to achieve employment opportunities and sustainable economic growth. The purpose of economic development itself includes controlling inflation and also improving people's lives. However, the main problem in economic development in general is the unequal distribution of income.

Unequal ownership of productive assets owned by everyone is one of the causes of income inequality (Todaro, 2006 in Wahyono 2017). Trade is one of the economic supports for the people involved in it. The income obtained by traders in the form of profits is used to increase capital or can meet their daily needs (Sudrajat, 2014)

In economics we talk about the market if there is a meeting between people who want to sell and people who want to buy a certain item or service at a price certain (Gilarso, 1992 in Suriadi, 2018). In the market there are many buyers and sellers who are conducting transactions, sellers who supply and sell agricultural products, plantations, livestock, fisheries and products of many types. This is where economic activity occurs, the seller is busy offering a variety of goods that he sells and buyers who are busy with the goods needed. In this way, the seller will get money from the sale.

The market plays an important role in the economic activities and economic development of a country. It is through the market that trading activities can proceed. The existence of the market also helps households (consumer households, producer households, and the government) obtain needs and or also income. In addition, the market is also able to create employment opportunities. Many people depend their livelihoods on economic activities in the 
market, both to find income and meet people's needs and are the economic center of society. Not only that, the market also functions as price stability, where market prices are used as a benchmark for measuring inflation and also policy makers by the government.

Modern markets which are generally owned by entrepreneurs who have large capital and high managerial expertise certainly have advantages compared to traditional markets. Susilo (2012) in Wahyono (2017) states that the defeat of traditional markets can be due to modern markets having several advantages including; can sell products at lower prices, guaranteed product quality, convenience of shopping, and the many choices of payment methods. In addition, the operational working time which is almost 14 hours / day in trading will certainly add to the attractiveness of consumers who in turn will certainly increase income. It is different from traditional market conditions, for example the problem of the long working hours. By noon, most consumers had gradually receded and the number of traders had decreased. This is in addition to the fact that the place is becoming increasingly uncomfortable, also because the seller's merchandise is incomplete (sold out). Facing the unbalanced competition between the traditional market and the modern market, the regional government of Bone Regency certainly does not remain silent seeing the development of the modern market. Various policies have been adopted through the formulation process relating to the management of traditional and modern markets. One of them is by doing renovations to improve the appearance of traditional markets so that buyers still feel comfortable shopping in the market and the market does not lose its buyers.

Palakka Market is one of the traditional markets in Bone Regency. Palakka Market is a potential market, because of its strategic location in the Bone area making it easy to reach for buyers in the village and in the city. Most of the fruit sold in this market comes from fruit farmers in the village. Palakka Market is also the market that has the most number of traders compared to other traditional markets.

\section{LITERATURE REVIEW}

By showing that trading in traditional markets has a significant role because traditional markets have always been a national indicator in the stability of facing an economic crisis. Besides that, in the traditional market, it is also one of the providers of staples, which will become a scarcity of staples when the traditional market does not function properly, the goods are cheap so it does not burden the community. Ulama also agreed on the ability to trade (buying and selling) as a case that has been practiced since the time of the Prophet Muhammad or even before until now. Because basically, Islam requires its people to try and endeavor in seeking sustenance. Everyone can choose a business and a job in accordance with their talents, skills and environmental factors. One area of work that may be chosen is to trade as long as it is in accordance with the requirements of the Shari'a of Allah and His Apostles. As in Surah An-Nisa; 29

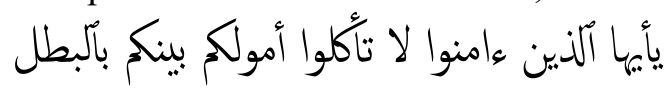

Translation: $O$ ye who believe! Do not eat your neighbor's wealth by taking a false path, except in trade on the basis of your liking. And do not kill yourself. Truly, Allah is Most Merciful to you.

Equitable community income, as a target, is a difficult problem to achieve, but the reduction in inequality is one of the benchmarks of successful development. Work can make someone earn income or wages for work done. Every head of family has a dependency of life on the income received to meet the needs of life, starting from the needs of food and clothing, shelter and various other needs. In Islam, necessity is indeed a reason for achieving a minimum income, while adequacy in a good standard of living is the most fundamental distribution of fees after that is only associated with work and private ownership (Wahyono, 2017)

In addition, one very important factor in trading business is capital. The role of capital in a business is very important because it is a means of producing goods and services. A business without capital as one of its production factors will not be able to run. In economics, the term capital is a concept with different meanings, depending on the context in which it is used and from what angle it looks at it (Wahyono, 2017). According to Bambang Riyanto (1998) capital is the result of production used to produce further. In its development then capital is emphasized on value, purchasing power uses or uses contained in capital goods.

Trading hours are also one of the factors that affect income. What is meant by trading hours is the length of time a fruit trader is in the market to sell his merchandise per month in units of hours. Work hours 
are the amount of time used for work activities. The intended work activity is work that generates money. Working hours can also be interpreted as the time someone uses to produce certain goods or services. According to the Big Indonesian Dictionary is the scheduled time for devices for employees and so on to work (Wahyono 2017).

Trading hours can also be said as working hours. Working hours are time to do work, can be carried out during the day and / or night. Working hours for workers in the private sector are regulated in Law No. 13 of 2003 concerning manpower, especially articles 77 through 85. Article 77 paragraph 1, Law no. $13 / 2013$ requires every employer to implement the provisions of working hours.

Trading experience is also a factor that affects income, trading experience can also be said as work experience. Work experience is knowledge or skills that have been known and mastered by someone who results from actions or work that has been done for a certain amount of time (Trijoko, 1980: 82).

\section{RESEARCH METHODS}

Type of research used is a quantitative method in which data collection is done by interview and questionnaire and direct observation. According to Sugiyono (2014) Quantitative research methods can be interpreted as a research method based on the philosophy of positivism, used to examine specific populations or samples, sampling techniques are generally carried out randomly, data collection using research instruments, data analysis is quantitative / statistical, namely explaining the relationship between variables by analyzing numerical data (numbers) using statistical methods through hypothesis testing.

\section{RESULTS AND DISCUSSION}

\subsection{Result}

1. Characteristics of Respondents Respondent characteristics in this study were 97 merchants who were representative to be presented as the eligibility of respondents in providing information about the identity of respondents. For more details, it will be described as follows:

a. Gender

Data on the number of respondents by sex can be seen in the following table 4.1:
Table 4.1

Respondents by Gender

\begin{tabular}{clcc}
\hline No & Gender & $\begin{array}{c}\text { Number of } \\
\text { Respondents }\end{array}$ & \% \\
\hline 1 & Men & 50 & 51.55 \\
\hline 2 & Women & 47 & 48.45 \\
\hline & Total & $\mathbf{9 7}$ & $\mathbf{1 0 0}$
\end{tabular}

Source: data processed, 2019

Based on the above data, it shows that the respondents based on the most sex are male with 50 people or $51.55 \%$ compared to the number of female respondents who totaled 47 people or $48.45 \%$.

b. Age

Data on the number of respondents by age can be seen in table 4.2 below:

Table 4.2

Respondents by Age

\begin{tabular}{cccc}
\hline No & Age & $\begin{array}{c}\text { Number of } \\
\text { Respondents }\end{array}$ & $\mathbf{\%}$ \\
\hline 1 & $<20$ Years & 0 & 0 \\
\hline 2 & $21-30$ Years & 37 & 38.14 \\
\hline 3 & $31-40$ Years & 46 & 47.42 \\
\hline 4 & $41-50$ Years & 12 & 12.37 \\
\hline 5 & $>50$ Years & 2 & 2.07 \\
\hline & Total & $\mathbf{9 7}$ & $\mathbf{1 0 0}$ \\
\hline
\end{tabular}

Source: processed data, 2019

Based on the data above, it shows that respondents based on age are $<20$ years old, no age 21-30 years there are 37 people or $38.14 \%$, age $31-40$ years there are 46 people or of $47.42 \%$, ages $41-50$ in year there were 12 people or $12.37 \%$ and $>50$ years there were 2 people or $2.07 \%$. So respondents based on age are the most respondents with ages 31-40 years.

c. Education Level

Data on the number of respondents based on education level can be seen in the following table 4.3:

Table 4.3

Respondents by Education

\begin{tabular}{clcc}
\hline No & $\begin{array}{c}\text { Level Education } \\
\text { Level }\end{array}$ & $\begin{array}{c}\text { Number of } \\
\text { Respondents }\end{array}$ & $\mathbf{\%}$ \\
\hline 1 & SD & 2 & 2.07 \\
\hline 2 & SMP & 10 & 10.31 \\
\hline 3 & SMA & 81 & 83.51 \\
\hline 4 & Diploma & 4 & 4,11 \\
\hline 5 & Bachelors & - & 0 \\
\hline & Total & $\mathbf{9 7}$ & $\mathbf{1 0 0}$
\end{tabular}

Source: processed data, 2019 
Based on the data above, it shows that respondents based on elementary education level there are 2 people or $2.07 \%$, there are 10 junior high schools or $10.31 \%$, there are 81 high schools or $83.51 \%$, there are 4 people Diploma or $4,11 \%$ and no Bachelor. So respondents based on their most recent education were respondents with a high school education.

d. Duration of Trading

Data on the number of respondents based on length of trading can be seen in the following table 4.4:

Table 4.4

\begin{tabular}{cccc}
\multicolumn{4}{c}{ Respondents by Length of Trading } \\
\hline No & Old Trading & $\begin{array}{c}\text { Number of } \\
\text { Respondents }\end{array}$ & $\mathbf{\%}$ \\
\hline 1 & $<1$ Year & - & 0 \\
\hline 2 & $1-10$ Years & 37 & 38.14 \\
\hline 3 & $11-20$ Years & 52 & 53.61 \\
\hline 4 & $21-30$ Years & 6 & 6.18 \\
\hline 5 & $>30$ Years & 2 & 2.07 \\
\hline & Total & $\mathbf{9 7}$ & $\mathbf{1 0 0}$ \\
\hline
\end{tabular}

Source: processed data, 2019

2. Description of Research Variables

1) Variable Capital Variables

The description of capital variables can be seen in Table 4.5 as follows:

Table 4.5

Descriptions of Variable Capital

\begin{tabular}{ccccccc}
\hline & \multicolumn{5}{c}{ FrequencyDistribution Respondents Answers } & Average Score \\
\cline { 2 - 7 } Question & 1 & 2 & 3 & 4 & 5 & \\
\hline $\mathrm{X} 1.1$ & 0 & 0 & 16 & 15 & 66 & 4,51 \\
& $(0 \%)$ & $(0 \%)$ & $(16.5 \%)$ & $(15.5 \%)$ & $(68.0 \%)$ & \\
\hline $\mathrm{X} 1.2$ & 0 & 0 & 23 & 13 & 61 & 4.39 \\
& $(0 \%)$ & $(0 \%)$ & $(23.7 \%)$ & $(13.4 \%)$ & $(62.9 \%)$ & \\
\hline $\mathrm{X} 1.3$ & 0 & 0 & 10 & 14 & 73 & 4.64 \\
& $(0 \%)$ & $(0 \%)$ & $(10.3 \%)$ & $(14.4 \%)$ & $(75.3 \%)$ & \\
\hline$\sum$ Trade Capital & 0 & 0 & 49 & 42 & 200 & 13.55 \\
& $(0 \%)$ & $(0 \%)$ & $(16.84 \%)$ & $(14.43) \%)$ & $(68.73 \%)$ & \\
\hline
\end{tabular}

Source: Processed from primary data, 2019

Based on the data in Table 5 it can be seen that the average score of the questions from 97 respondents, the largest is the question third, amounting to 4.64. This question has the biggest
Based on the data above, it shows that respondents based on length of trading are $<1$ year no, 1-10 years there are 37 people or $38.14 \%, 11-20$ years there are 52 people or $53.61 \%, 21-30$ years there 6 people or $6.18 \%$, and $>30$ years there were 2 people or $2.07 \%$. So respondents based on the length of trading the most are respondents with trading profits for 11-20 years. 


\begin{tabular}{|c|c|c|c|c|c|c|}
\hline \multicolumn{7}{|c|}{ Jurnal Ilmiah Ekonomi Islam, 6(02), 2020, 308} \\
\hline \multicolumn{7}{|c|}{$\begin{array}{c}\text { Table } 4.6 \\
\text { Description of Trading Hours Variables }\end{array}$} \\
\hline \multirow{2}{*}{ Question } & \multicolumn{5}{|c|}{ Frequency Distribution Respondents Answers } & Average Score \\
\hline & 1 & 2 & 3 & 4 & 5 & \\
\hline $\mathrm{X} 2.1$ & $\begin{array}{c}0 \\
(0 \%)\end{array}$ & $\begin{array}{c}0 \\
(0 \%)\end{array}$ & $\begin{array}{c}14 \\
(14.4 \%)\end{array}$ & $\begin{array}{c}10 \\
(10.3 \%)\end{array}$ & $\begin{array}{c}73 \\
(75.3 \%)\end{array}$ & 4,60 \\
\hline $\mathrm{X} 2.2$ & $\begin{array}{c}0 \\
(0 \%)\end{array}$ & $\begin{array}{c}0 \\
(0 \%)\end{array}$ & $\begin{array}{c}22 \\
(22.7 \%)\end{array}$ & $\begin{array}{c}12 \\
(12.4 \%)\end{array}$ & $\begin{array}{c}63 \\
(64.9 \%)\end{array}$ & 4.42 \\
\hline $\mathrm{X} 2.3$ & $\begin{array}{c}0 \\
(0 \%)\end{array}$ & $\begin{array}{c}0 \\
(0 \%)\end{array}$ & $\begin{array}{c}20 \\
(20.3 \%)\end{array}$ & $\begin{array}{c}8 \\
(8.2 \%)\end{array}$ & $\begin{array}{c}69 \\
(71.1 \%)\end{array}$ & 4.50 \\
\hline Trading Hours & $\begin{array}{c}0 \\
(0 \%)\end{array}$ & $\begin{array}{c}0 \\
(0 \%)\end{array}$ & $\begin{array}{c}56 \\
(19.24 \%)\end{array}$ & $\begin{array}{c}30 \\
(10.31 \%)\end{array}$ & $\begin{array}{c}205 \\
(70.45 \%)\end{array}$ & 13.53 \\
\hline
\end{tabular}

Source: Processed from primary data, in 2019

Based on data from Table 6 it appears that the average score of questions from 97 respondents, the largest is the question first is 4.60 . This question has the biggest contribution in the trading hours variable,

this means that trading hours can increase the income of the fruit traders in the Palakka market in Bone Regency.

3) Trading Experience Variables

The description of trading experience variables can be seen in Table 4.7 as follows:

Table 4.7

Description of Trading Experience Variables

\begin{tabular}{ccccccc}
\hline & \multicolumn{5}{c}{ FrequencyDistribution Respondents Answers } & Average Score \\
\cline { 2 - 7 } Question & 1 & 2 & 3 & 4 & 5 & \\
\hline X3.1 & 0 & 0 & 18 & 16 & 63 & 4,46 \\
& $(0 \%)$ & $(0 \%)$ & $(18.6 \%)$ & $(16.5 \%)$ & $(64.9 \%)$ & \\
X3.2 & 0 & 0 & 25 & 18 & 54 & 4.29 \\
& $(0 \%)$ & $(0 \%)$ & $(25.8 \%)$ & $(18.6 \%)$ & $(55.7 \%)$ & \\
\hline X3.3 & 0 & 0 & 21 & 10 & 66 & 4.45 \\
& $(0 \%)$ & $(0 \%)$ & $(21.6 \%)$ & $(10.3 \%)$ & $(68.0 \%)$ & \\
\hline$\sum$ Trading Experience & 0 & 0 & 64 & 44 & 183 & 13.22 \\
& $(0 \%)$ & $(0 \%)$ & $(21.99 \%)$ & $(15.12 \%)$ & $(62.89 \%)$ & \\
\hline
\end{tabular}

Source: Processed from primary data, in 2019

Based on the data in Table 7 it appears that the average score of questions from 97 respondents, the largest is the question first is 4.46 . This question has the biggest contribution in the variable of trading

experience, this means that trading experience can increase the income of the fruit traders in the Palakka market in Bone Regency.

4) Trader Income Variable The

description of the merchant income variable, can be seen in Table 4.8 as follows:

Table 4.8

Description of Trader Income Variables

\begin{tabular}{ccccccc}
\hline & \multicolumn{5}{c}{ FrequencyDistribution Respondents Answers } & \multirow{2}{*}{ Average Score } \\
\cline { 2 - 6 } Question & 1 & 2 & 3 & 4 & 5 & \\
\hline Y.1 & 0 & 0 & 16 & 28 & 53 & 4,38 \\
& $(0 \%)$ & $(0 \%)$ & $(16.5 \%)$ & $(28.9 \%)$ & $(54.6 \%)$ & \\
\hline Y.2 & 0 & 0 & 10 & 14 & 73 & 4.64 \\
& $(0 \%)$ & $(0 \%)$ & $(10.3 \%)$ & $(14.4 \%)$ & $(75.3 \%)$ & \\
\hline Y.3 & 0 & 0 & 24 & 12 & 61 & 4.39 \\
& $(0 \%)$ & $(0 \%)$ & $(24.7 \%)$ & $(12.4 \%)$ & $(62.9 \%)$ & \\
\hline Trader Income & 0 & 0 & 50 & 54 & 187 & 13.41 \\
& $(0 \%)$ & $(0 \%)$ & $(17.18 \%)$ & $(18.56) \%)$ & $(64.26 \%)$ & \\
\hline
\end{tabular}

Source: Processed from primary data, 2019 


\section{Jurnal Ilmiah Ekonomi Islam, 6(02), 2020, 309}

Based on data from Table 8 it can be seen that the average score of questions from 97 respondents, the largest is the question the second is 4.64. This question has the largest contribution in the variable income of traders, this means that the income of traders can improve the welfare of the living standards of fruit traders in the Palakka market in Bone Regency.

3. Hypothesis Test

a. Simultaneous Analysis (Test F)

Simultaneous testing (test F) is carried out to find out whether all independent variables $X_{i}$ (trading capital, trading hours and trading experience) simultaneously have a significant effect on the dependent variable of trader income $(\mathrm{Y})$ in the Palakka district market Bone. The test is carried out based on the following test hypotheses:

$\mathrm{H}_{0} ; \beta_{\mathrm{i}}=0$ against $\mathrm{H}_{\mathrm{a}} ; \beta_{\mathrm{i}} \neq 0$

The testing criteria:

If $\mathrm{F}_{\text {arithmetic }} \mathrm{F}_{\text {table }}$ or $\mathrm{p}_{\text {value }}<0.05, \mathrm{H}_{0}$ is rejected and $\mathrm{H}_{\mathrm{a}}$ accepted

If $\mathrm{F}_{\text {arithmetic }}<\mathrm{F}_{\text {table }}$ or $\mathrm{p}_{\text {value }}>0.05, \mathrm{H}_{0}$ is accepted and $\mathrm{H}_{\mathrm{a}}$ denied

if $\mathrm{H}_{0}$ is received, then the beta coefficient regression is not significantly different from 0 so that the regression results obtained can not be used to perform statistical estimation and can not be used to measure whether the independent variable $X_{i}$ influence the dependent variable $\mathrm{Y}_{\mathrm{i}}$.Conversely, if $\mathrm{H}_{0}$ Hrejected or $_{a}$ accepted, then the beta regression coefficients significantly different from 0 so that the regression results obtained can be used to make a statistical prediction. Thus the regression equation can be used to measure, whether the independent variable $X_{i}$ affects the dependent variable $Y_{i .}$.

Table 4.9

Simultaneous Test Results

ANOVA $^{\mathrm{a}}$

\begin{tabular}{|l|r|r|r|r|r|}
\hline Model & \multicolumn{1}{|c|}{$\begin{array}{c}\text { Sum of } \\
\text { Squares }\end{array}$} & Df & $\begin{array}{c}\text { Mean } \\
\text { Square }\end{array}$ & F & Sig. \\
\hline 1 Regression & $31,360.000$ & 3 & 4,576 & & $13,728^{\mathrm{b}}$ \\
Residual & 13570 & 93 & .146 & & \\
Total & 27,299 & 96 & & & \\
\hline
\end{tabular}

a. Dependent Variable: Trader Income

b. Predictors: (Constant), Trading Experience, Trading Hours, Trading Capital

Source: processed data, 2019
Table 4.9 explains that all independent variables $\mathrm{X}_{\mathrm{i}}$ (trading capital, trading hours and trading experience) have a positive and significant effect on the dependent variable $\mathrm{Y}$ (merchant income). The $\mathrm{F}$ value is calculated 31.360 with a significance level of 0.000 or a $\mathrm{p}_{\text {value }}<0.05$. Based on the hypothesis testing criteria, then $\mathrm{H}_{0}$ is rejected and $\mathrm{H}_{\mathrm{a}}$ accepted. This means that simultaneously all independent variables have a real difference with 0 .

At the same time, the regression analysis obtained can be used to carry out statistical estimates for the measurement of influence. Simultaneous effect of variable $\mathrm{X}_{\mathrm{i}}$ (trade finance, trading hours and trading experience) to variable $\mathrm{Y}$ (income traders), it can be seen also from simultaneous determination coefficient $\left(\mathrm{R}^{2)}\right.$.This can be seen from the results of the Simultaneous Determination analysis in table 4.10 as follows:

Table 4.10

Determination Test Results

Summary

\begin{tabular}{|l|c|c|c|c|}
\hline Model & $\mathrm{R}$ & $\begin{array}{c}\mathrm{R} \\
\text { Square }\end{array}$ & $\begin{array}{c}\text { Adjusted } \\
\text { R Square }\end{array}$ & $\begin{array}{c}\text { Std. Error of the } \\
\text { Estimate }\end{array}$ \\
\hline 1 & $.709^{\mathrm{a}}$ & .503 & .487 & .38199 \\
\hline
\end{tabular}

a. Predictors: (Constant), Trading Experience, Trading Hours, Trading Capital

Source: processed data, 2019

From Table 4.10 above shows that the value of the correlation coefficient (R) shows the relationship between variable $\mathrm{X}_{\mathrm{i}}$ (trading capital, trading hours and trading experience) with variable $\mathrm{Y}$ (merchant income) of Palakka market in Bone Regency. Correlation coefficient (R) of 0.709 can be interpreted that there is a positive and unidirectional relationship between variable $X_{i}$ with variable $Y . R$ value $^{2}=0.503$. This means, the effect of variable $X_{i}$ (trading capital, trading hours and trading experience) simultaneously on variable $\mathrm{Y}$ (merchant income) is $50.3 \%$ and the effect of other variables is $49.7 \%$. This influence is quite good because it is greater than $50 \%$ and significant $\left(\mathrm{P}_{\text {value }}\right)=0,000$ (very far below the critical value of the test $\alpha=0.05$ ).

b. Partial Analysis ( $t$ test)

Before presenting the discussion about partial testing, first the regression analysis results from the research data will be presented. Presentation of the results of the analysis is intended to express the regression equation obtained in research this market classified in traditional markets in accordance with 


\section{Jurnal Ilmiah Ekonomi Islam, 6(02), 2020, 310}

Minister of Home Affairs Regulation No. 20 years 2019, chapter II, article 4. Based on observations and interviews, Traditional Market Cekkeng has the potential to improve the economy of the community, in this case traders in the market, as for the potential of the market Cekkeng are:

Table 4.11

Partial Test Results

\section{Coefficients}

\begin{tabular}{|c|c|c|c|c|c|}
\hline \multirow[b]{2}{*}{ Model } & \multicolumn{2}{|c|}{$\begin{array}{c}\text { Unstandardized } \\
\text { Coefficients }\end{array}$} & \multirow{2}{*}{$\begin{array}{c}\text { Standardized } \\
\text { Coefficients } \\
\text { Beta }\end{array}$} & \multirow[b]{2}{*}{$\mathrm{t}$} & \multirow[b]{2}{*}{ Sig } \\
\hline & B & $\begin{array}{l}\text { Std. } \\
\text { Error }\end{array}$ & & & \\
\hline 1 (Constant) & .525 & .421 & & 1,248 & .215 \\
\hline Trade Capital & $\begin{array}{c}.076 \\
.450 .000\end{array}$ & & & 5,508 & .420 \\
\hline Hours Trading & .078 .270 & & .265 & 3,412 & .001 \\
\hline $\begin{array}{c}\text { Trading } \\
\text { Experience }\end{array}$ & .065 .229 & & .194 & 2,982 & .004 \\
\hline
\end{tabular}

a. Dependent Variable: Trader Income

Source: processed data, 2019

Statistically, the test hypothesis is:

$\mathrm{H}_{0} ; \beta_{\mathrm{i}}=0$ against $\mathrm{H}_{\mathrm{a}} ; \beta_{\mathrm{i}} \neq 0$.

Significance Level $(\alpha)=0.05$

Test criteria:

If $\mathrm{t}_{\text {arithmetic }}>\mathrm{t}_{\text {table }}$, then $\mathrm{H}_{0}$ is rejected and $\mathrm{H}_{\mathrm{a}}$ is accepted with $\alpha=0.05$

If $\mathrm{t}_{\text {arithmetic }}<\mathrm{t}_{\text {table }}$, then $\mathrm{H}_{0}$ is accepted and $\mathrm{H}_{\mathrm{a}}$ is rejected with $\alpha=0.05$

From Table 11 it can be seen that partially, all the analyzed variables have different levels of probability (significance level).

a. The variable of trading capital has a positive and significant influence on the income of the Palakka fruit market traders in Bone Regency, based on the results of partial testing using the $t$ value, found the t-count value for the trading capital variable of 5,508 with a t table value of 1,660 and a significance level of $0,000(p<5 \%)$. The results of this test conclude that the hypothesis for the variable of trading capital that has been proposed is supported by empirical evidence, meaning that the variable of capital capital has a significant effect on the income of fruit traders in the Palakka market in Bone Regency with the assumption of variable hours of trading and constant trading experience.

b. The trading hours variable has a positive and significant effect on the income of the Palakka fruit market traders in Bone Regency, based on the results of partial testing using the $t$ value, found the t-value for the trading hours variable is 3,412 with a $t$ table value of 1,660 and a significance level of $0,001(\mathrm{p}<5 \%)$. The results of this test conclude that the hypothesis for the proposed trading hours variable is supported by empirical evidence, meaning that the trading hours variable has a significant effect on the income of the fruit traders in the Palakka market in Bone Regency with the assumption that the variable of trading capital and constant trading experience.

c. The trading experience variable has a positive and significant impact on the income of the Palakka fruit market traders in Bone Regency, based on partial test results using the $t$ value, found the t-value for the trading experience variable of 2.982 with a t table value of 1.660 and a significance level of $0.004(\mathrm{p}<5 \%)$. The results of this test conclude that the hypothesis for the trading experience variable that has been proposed is supported by empirical evidence, meaning that the trading experience variable has a significant effect on the income of the Palakka Bone fruit market traders with the assumption that the variable of trading capital and trading hours are constant.

Thus the hypothesis $\mathrm{H}_{0}$ is rejected and the hypothesis $\mathrm{H}_{\mathrm{a}}$ accepted. This means, the regression coefficient obtained from the analysis is significantly different from 0 at a confidence level of $95 \%$. From the results of the analysis obtained all variables that have a regression coefficient significantly different from zero, on the basis of these results, the regression equation obtained can be used to perform statistical estimates, including for forecasting and the regression equation obtained is:

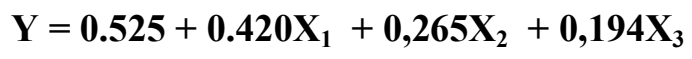

The multiple regression equation can be explained as follows: 


\section{Jurnal Ilmiah Ekonomi Islam, 6(02), 2020, 311}

a) Coefficient $\mathrm{b}_{0}=0.525$ means that if the variable of trading capital $\left(\mathrm{X}_{1}\right)$, hours of trading $\left(\mathrm{X}_{2}\right)$ and experience of trading $\left(\mathrm{X}_{3}\right)$ do not change (constant), then the income of traders $(\mathrm{Y})$ in the Palakka market in Bone Regency will not change.

b) Coefficient $b_{1}=0.420$ means that every increase in the variable of trading capital $\left(\mathrm{X}_{1}\right)$, the income of traders (Y) in the fruit of the Palakka market in Bone Regency increases by $42 \%$.

c) Coefficient $b_{2}=0.265$ means that each increase in the trading hours variable $\left(\mathrm{X}_{2}\right)$, the income of traders (Y) in the Palakka market in Bone Regency increases by $26.5 \%$.

d) Coefficient $b_{3}=0.194$ means that each increase in the variable income of trade $\left(X_{3}\right)$, then the income of traders $(\mathrm{Y})$ fruit Palakka market Bone Regency increased by $19.4 \%$.

From the equation it is also known that all regression coefficients of the analysis result are positive. This means, the relationship between the dependent variable $Y_{i}$ with the independent variable $X_{i}$ has the same direction of change. Thus, if the intensity of implementation is carried out on certain independent variables, or on all the independent variables together it can be increased, then the income of the fruit traders in the Palakka market in Bone Regency will increase. And vice versa if the intensity of implementation is carried out on certain independent variables, or on all independent variables jointly reduced, then the income of fruit traders in the Palakka market in Bone Regency will decrease.

\subsection{Discussion}

1. Effect of Trading Capital on Trader Income

Based on the results of statistical analysis in this study, it was found that trading capital had a positive and significant effect on the income of the fruit traders in the Palakka market in Bone Regency, this meant that the first hypothesis (H1) was accepted and it could be concluded that trading capital was increasingly increases, the level of merchant income achieved is also increasing. These results indicate that trading capital significantly influences the income of the Palakka Bone Regency fruit market traders. If trading capital runs effectively, then this will push traders to the maximum level of income. Thus, the hypothesis stating that trading capital has a positive and significant effect on the income of the fruit traders in the Palakka market in Bone Regency is accepted.

Trade capital is goods or money which together with factors of production and labor produce new goods. Because trading capital produces new goods or is a tool to cultivate income, it will create impetus and interest to set aside his wealth and production results with a productive intention and not for consumptive purposes. Trading capital can be created to hold back in the form of consumption, with the aim of income will be even greater in the future. Economic development will be implemented if capital formation goes well. Therefore a successful development will continue to try to increase its capital.

Trading capital and income is a form that has a close relationship. Variable in trading capital greatly affects the income received by traders. Trading capital is used by traders to buy various merchandise and its processing. With a relatively larger capital, it will enable traders or business owners to add variety of commodity commodities so that consumers are relatively more interested in purchasing goods in that place. This will increase trader income. The size of the trading capital used in the business will certainly affect the income earned by the Palakka market fruit trader in Bone Regency. In order for the trading business to run well, sufficient capital is needed. In addition, trading capital is a factor that needs to be taken into account in determining trading income for fruit traders in the Palakka market in Bone Regency to improve welfare and a better economy.

Relatively large capital will be increasingly possible to achieve greater income. With relatively large capital, the fruit seller of the Palakka market in Bone Regency makes it possible to increase the quantity and variety of commodity commodities so that the profits will be even greater. The income received by the Palakka market in Bone Regency is highly dependent on capital ownership. The greater the capital or factor of production owned, the higher the income it receives. The business capital of Palakka Bone Regency fruit market traders themselves varies greatly in size, depending on the type of commodity traded by traders.

In terms of owning business capital, many traders do not have enough capital to provide their merchandise. So that many traders who only sell goods other than their own merchandise (deposit), so that inevitably traders have to share the profits they 


\section{Jurnal Ilmiah Ekonomi Islam, 6(02), 2020, 312}

get. There are also many traders whose business capital comes from loans, so their income is reduced to repay loans. Whereas traders with sufficient capital can expand their trading places (merchandise lots). So they can add more and more complete variants and quantities of their commodity commodities. Thus of course it can attract customers and increase revenue earned. Although not all big capital always gets a big income too. However, by increasing business capital traders can increase greater income. This is in accordance with research Anton Sudrajat (2014) with the research title "Analysis of Factors Affecting Muslim Trader Income". The results showed that trading capital had a significant positive effect on the income of Muslim traders.

\section{Effect of Trading Hours on Trader Income}

Based on the results of statistical analysis in this study, it was found that trading hours had a positive and significant effect on the income of fruit traders in the Palakka market in Bone Regency, this meant that the second hypothesis (H2) was accepted and it could be concluded that trading hours were increasing then the level of merchant income achieved is also increasing. These results indicate that trading hours significantly affect the income of Palakka fruit market in Bone Regency. If trading hours run effectively, then this will push the trader to the maximum level of income. Thus, the hypothesis which states that trading hours have a positive and significant effect on the income of the fruit traders in the Palakka market in Bone Regency is accepted.

Trading hours or opening a business are important factors in carrying out business activities, because the higher business opening hours that we provide to open a business, the probability of turnover received by traders will be higher. The effect of opening hours of business on merchant income is significant. Therefore, the business owner or trader must be more active in utilizing peak hours to sell his merchandise, especially paying attention to the quality of his merchandise and being good at providing goods price strategies to increase revenue. Each additional operating time will further open up opportunities for increased sales turnover. Work time allocation theory is based ontheory utility namely that individual time allocation is faced with two choices, namely working or not working to enjoy their free time. By working it means that it will generate income which in turn will increase income. The more time someone uses to work means the more income he will get.

The more hours of work done by the fruit traders of the Palakka market in Bone Regency in conducting trading activities, the greater the chance of earning the income that will be earned by the trader. However, in its application, the addition of working hours certainly does not necessarily spend time from morning to night just to trade for the sake of increasing income. Palakka Bone Regency fruit traders can only increase their working hours by optimizing the market hours of the market. Because it cannot be denied, excessive working hours will actually reduce the productivity of traders. For the opening hours of traders themselves vary depending on the type of commodity being traded and the location they sell. This is in accordance with Budi Wahyono's research (2017) with the research title "Analysis of Factors Affecting Trader Income in Bantul Market, Bantul Regency". The results showed that there was a positive and significant effect of working hours on merchant income.

\section{Effect of Trading Experience on Trader Income}

Based on the results of statistical analysis in this study, it was found that trading experience had a positive and significant effect on income of fruit traders in the Palakka market in Bone Regency, this meant that the third hypothesis (H3) was accepted and it could be concluded that increasing trading experience then the level of merchant income achieved is also increasing. These results indicate that trading experience significantly influences the income of the Palakka fruit market in Bone Regency. If the experience of trading works effectively, then this will push the trader to the maximum level of income. Thus, the hypothesis which states that trading experience has a positive and significant effect on the income of the fruit traders in the Palakka market in Bone Regency is accepted.

Trading experience is one of the factors that can determine the sustainability of a business, because the longer a business is run, then the business can develop the business step by step. Trading experience is related to the time period of the business being run, because the longer the business is running, then the business has survival and development. Therefore, business owners must be optimistic in running existing businesses to be better in the future, because experience is a good teacher where experience in 


\section{Jurnal Ilmiah Ekonomi Islam, 6(02), 2020, 313}

trying can be used as a guide so as not to make mistakes that have occurred, in order to increase trader income. The length of a business can lead to experience of doing business, where experience can affect the observation of traders in behavior.

The length of a business opening can affect the level of income, the length of time a business person is engaged in his field of business will affect his productivity (his professional ability / expertise), so as to increase efficiency and be able to reduce production costs smaller than the sales. The longer the field of business will further increase the knowledge of consumer tastes or behavior and more and more business relationships and customers who successfully captured. So that the number of customers who are netted will increase revenue and ultimately the profits will increase. This is in accordance with research Anton Sudrajat (2014) with the research title "Analysis of Factors Affecting Muslim Trader Income". The results showed that trading experience had a significant positive effect on the income of Muslim traders.

\section{CONCLUSION}

Having conducted a series of discussions and analysis, the authors draw conclusions that:

a. Trading capital has a positive and significant impact on the income of the Palakka market in Bone Regency. Based on partial test results using the $t$ value, found the $t$-value for the trading capital variable of 5.508 with a $t$ table value of 1.660 and a significance level of $0.000(\mathrm{p}<5 \%)$.

b. Trading hours had a positive and significant impact on the income of the Palakka market in Bone Regency. Based on the partial test results using the $t$ value, it was found the $t$-value for the trading hours variable was 3,412 with a t table value of 1,660 and a significance level of 0.001 $(\mathrm{p}<5 \%)$.

c. The trading experience had a positive and significant impact on the income of the Palakka market in Bone Regency. Based on the partial test results using the $t$ value, it was found t-value for the trading experience variable of 2.982 with a t table value of 1.660 and a significance level of $0.004(\mathrm{p}<5 \%)$.

\section{BIBLIOGRAPHY}

AL-Quran and Translation

Afifi, Zulfa Nur. (2017). Analysis of Factors Affecting Wonosobo Main Market Traders' Revenues After Temporary Fire Relocation in 2014. Thesis (Not Published) Sunan Kalijaga State Islamic University, Yogyakarta.

Case, Karl E. \& Ray C Fair. (2007). Economic Principles. Jakarta: Erlangga Publisher.

Helen, Malinda. 2017. Analysis of SME Business Development Strategies to Increase Employee Income According to Islamic Economic Perspective. Raden Intan State University Lampung.

https://artonang.blogspot.com. Definition of Working Hours According to the Law (Online). (Accessed on 10 September 2019)

Irawan \& Suparmoko. (1992). Development Economics. Bpfe- Yogyakarta, Yogyakarta

Giang, Randi R. 2013. The Effect of Income on Building Labor Consumption in Pineleng Subdistrict. EMBA Journal Vol. 1 No. June 3, 2013, pp. 284-256. Sam Ratulangi University Manado.

Komang, I Adi Antara. 2016. Some Factors That Affect the Income of Street Vendors in West Denpasar District. E-Journal EP Unud, 5 [10]: 1265-1291. UdayanaUniversity

Manulang. 1984. Personality Management, Jakarta: Ghalia Indonesia

Menuk, Christina S and Tony Susilo Wibowo. 2016. Factors Affecting the Income of Street Vendors in PKL Case Study in Surabaya. Economy_ISSN Magazine No. 1411-9501_Vol. XXI No. 2 Dec 2016. PGRI Adi Buana University Surabaya Surabaya

Mustafa Edwin Nasution, Exclusive Introduction to Islamic Economics, (Jakarta: Kencana Renada Media Group, 2007), p. 132

Putu, Ni Ria Sasmitha and AA Ketut Ayuningsasi. 2017. Factors That Affect Craftsmen's Income in the Bamboo Handicraft Industry in Belega Village, Gianyar Regency. E-Journal EP Unud, 6 [1]: 64-84.

Rai, Ni Artini. 2019. Analysis of Factors Affecting MSME Revenue in Tabanan Regency. http: // journal.unmastaram.ac.id \index.php / GARA Vol 13, No. 1. Tabanan University. 
Jurnal Ilmiah Ekonomi Islam, 6(02), 2020, 314

Riyanto, Bambang. 1998. Fundamentals of Corporate Expenditures. (Online) (www.ambyarberbagi.com, accessed 10 September 2019)

Ruli, Andre Mumu. 2015. Factors That Influence the Level of Community Entrepreneurial Income in Malalayang Village II. E-Journal "Volume IV. No.3

Simanjuntak, Payaman J. 2001. Introduction to Human Resource Economics.Jakarta: Fe-Ui Issuing Institution.

Simanjuntak, \& Ekklesia, J. (2019). The Effect of Product Design, Brand Image, and Price on Purchasing Decisions of Tupperware Products in the Faculty of Economics and Business, University of North Sumatra. University of Northern Sumatra.

Skripsi.mamanjemen.blogspot.com. understanding of work experience. (On line). (Accessed on the steps of 10 September 2019)

Sondakh, Ernia and Rine Kaunang, Paulus Adrian Pangemanan. 2016. Factors Affecting Rice Traders' Income in Facing Price Fluctuations in Manado City. ASE - Volume 12 Number 1A, March 2016:.

103-120Sudrajat, Anton. 2014. Analysis of Factors Affecting Muslim Trader Income. ADDIN, Vol. 8, No. 1, February 2014
Sugiyono. (2014). Educational Research Methods Quantitative, Qualitative, and $R \& D$ Approaches. Bandung.Alfabeta.

Sukirno, Sadono. (2006). Introduction to Macroeconomics. Jakarta: Pt Raja GrafindoPersada.

Suriadi, Ahmad and Ahmad Suhendri. 2018. Determinant Analysis of Traders' Income Factors in the Rembiga Market in Selaparang, Mataram City. Competitive Journal: Media Information Economic Development, Management and Accounting Vol 4 No. 2, September 2018.

Utami, Setyaningsih Sri And Edi Wibowo. (2013). The Effect of Working Capital on Income with Operating Time as a Moderation Variable (Survey on Market Traders Klithikan Notoharjo Surakarta). Journal of Economics and Entrepreneurship Vol. 13, No. 2, October 2013: Pg. 171-180.

Wahyono, Budi. 2017. Analysis of Factors Affecting Trader Income in Bantul Market, Bantul Regency. Journal of Education and Economics, Volume 6, Number 4, 2017. Yogyakarta State University. 